\title{
Seedstalk production of mountain big sagebrush enhanced through short-term protection from heavy browsing
}

\author{
FRED J. WAGSTAFF AND BRUCE L. WELCH
}

\begin{abstract}
Mountain big sagebrush (Artemisia tridentata ssp. vaseyana Nutt.) is an important browse species on many key mule deer winter ranges in the western United States. Big sagebrush on many of those ranges is declining due to the lack of recruitment. Plants subjected to heavy $>80 \%$ use) browsing produce 50 to $93 \%$ fewer seedstalks than those not subject to such use. The objectives of this study were to determine: (1) whether protection from browsing for 1 winter would increase the number of seedstalks the following fall; (2) if protection increased length of seedstalk; (3) if there is a relationship between seedstalk length and number of seeds per seedstalk; and (4) if increasing seed production increased seedling establishment. Fifty-eight plots containing 344 plants at 4 sites in north-central Utah were established. At each plot, plants were randomly assigned to be either protected or browsed. The protected plants produced significantly $(P<0.05)$ more seedstalks than those browsed during the previous winter. Length of seedstalks on a given plant and among plants showed considerable variation, and the data indicated no clear differences between average seedstalk length on browsed and protected plants. Seed per unit length of seedstalk was also highly variable. No seedlings were found during 7 years of observations of the original plot or in 4 years for the 57 plots established in 1986, regardless of the numbers of seedstalks on a plant. Seed production does not appear to be a limiting factor in seedling establishment for the study populations.
\end{abstract}

Key Words: Artemisia tridenta ssp. vaseyana, mountain big sagebrush, seedstalk production, browsing, seed production

Big sagebrush (Artemisia tridentata Nutt.) is a major plant in a large and important ecosystem in western North America (Beetle 1960). Within the literature most early studies are descriptive in nature and a great number of papers deal with control by various means. The investigations of the effects of various control and management strategies revealed much about the biology of big sagebrush, and several workers have published studies about its taxonomy (Winward and Tisdale 1977, Hironaka et al. 1983, McArthur 1983, Winward 1983). Of the 4 major subspecies of big sagebrush, mountain big sagebrush (A. tridentata ssp. vaseyana) was utilized by wintering mule deer most frequently along the Wasatch Front of Utah. It also is important as browse in other areas (Nagy 1979, McAdoo and Klebenow 1979, Welch 1983b, Personius et al. 1987, Young et al. 1989). Some localities are known to produce plants that are exceptionally preferred (Welch 1983a, Welch et al. 1986, McArthur et al. 1987).

In sagebrush stands on the foothills adjacent to the urban area known as the Wastach Front of Utah, much plant mortality of mountain big sagebrush is evident and is of concern because urban encroachment is reducing the area available for wintering mule deer.

Heavy winter browsing ( $>80 \%$ use) is believed to reduce the

Range economist and principal research plant physiologist, Intermountain Research Station, Forest Service, USDA, Ogden, Utah 84401 .

The use of trade or firm names in this paper is for reader information and does not imply endorsement by the USDA of any product or service.

Manuscript accepted 6 May 1990. number of seedstalks produced the following growing season. If continued, heavy browsing can reduce plant vigor and may cause large reductions in plant stands (Smith 1949, Smith and Gaufin 1950, Cook and Stoddard 1960, Welch et al. 1987, McArthur et al. 1988).

We believe the low production of seedstalks may be due to heavy mule deer browsing, and the resulting low seed production per sagebrush plant may be an important factor in the lack of recruitment in mountain big sagebrush populations along the Wasatch Front. We developed this study to determine: (1) if protection from browsing for 1 winter would increase the number of seedstalks, (2) if protection increased length of seedstalks, (3) if seed production was correlated with seedstalk length, and (4) if increased seed production increased seedling establishment.

\section{Methods and Materials}

This study was conducted in the foothills of the Wasatch mountains in north-central Utah near the city of Provo. The Hobble Creek and Pleasant Grove sites near the lower edge of the ssp. vaseyana type are about $1,027 \mathrm{~m}$ elevation and the Diamond Fork site is slightly higher, about $1,646 \mathrm{~m}$. Soils, sampled at several locations at all of the sites, were derived from limestone parent material. The soils are alluvial and of a loamy texture with no restrictive layers. A chemical analysis of the soils found no major nutritive or chemical deficiencies or restrictions.

The 4 sites chosen for study are used as winter range by mule deer. At all sites big sagebrush plants exhibit the effects of heavy browsing. Cattle graze the Diamond Fork area on a rest rotation system, and the other 3 sites have been closed to livestock grazing for over 20 years. Sagebrush populations in each of the study areas have $40-50 \%$ dead plants and no observed recruitment for the past several years.

The site named Hobble Creek 1 includes the area fenced in 1983 to provide foundation seed for 'Hobble Creek' mountain big sagebrush. Since the area was quite small, only 1 plot was established. Six years of observation for this site are included in tables 1 and 4 . The other sites were studied to expand the data base and to determine whether a one-season rest would have a significant effect on seedstalk production.

At each site plants of approximately the same size were randomly selected and grouped into plots of 4,6 , or 20 plants arranged so that no plant in a plot was more than $61 \mathrm{~m}$ away from the most distant plant in that plot. The plots were widely distributed across each site in case environmental differences within the site were present but not readily apparent. At the Hobble Creek 2 site, 21 plots of 6 plants each were established; at Pleasant Grove 27 plots of 6 plants each; at Diamond Fork 9 plots of 4 plants; and the Hobble Creek 1 site had 1 plot of 20 plants. A total of 58 plots with 344 plants total were included. At each plot, the treatment was assigned randomly to half of the plants. To prevent browsing, a wire cage was constructed of net field fencing sides and chicken wire tops supported by 2 steel posts $2 \mathrm{~m}$ tall, large enough to assure $30 \mathrm{~cm}$ of space around the plant and tall enough to provide $30 \mathrm{~cm}$ of headspace. Seedstalks were counted and measured on all of the 
plants on the Hobble Creek 1 plot from 1984 to 1989, and on the other plots in the fall of 1986 to 1989 . At each site we selected 100 seedstalks at random from protected plants and a like number from browsed plants. Four size classes and 2 form classes were used to stratify the sample, and the number of seeds per stalk were counted. Statistical analysis was completed using Student's $t$-test and analyses of variance procedures of the Minitab (tm) software package (Ryan et al. 1985). Comparisons on seedstalk numbers and length were made between treatments for 6 years on the Hobble Creek 1 plot and 1 year on all other plots. The number-ofseeds per stalk study was conducted for 1987 only.

\section{Results and Discussion}

Analyses of data for the Hobble Creek 1 site indicate a significant treatment difference in seedstalk production in each of the 6 years. The data in Table 1 show a trend toward increasing seed production for each year of protection. How long this trend will continue is uncertain. On this plot the relatively low plant density may be a partial explanation of this continual increase.

Table 1. Average number of seedstalks per plant on mountain big sagebrush at one site (Hobble Creek 1) in north central-Utah.

\begin{tabular}{lccc}
\hline \hline Year & Protected & Browsed & Increase \\
\hline 1984 & 116 & 6 & $110^{*}$ \\
1985 & 165 & 11 & $154^{*}$ \\
1986 & 183 & 12 & $171^{*}$ \\
1987 & 206 & $65^{*}$ & $141^{*}$ \\
1988 & 240 & 18 & $222^{*}$ \\
1989 & 336 & 6 & $330^{*}$ \\
\hline
\end{tabular}

*Significant at the 0.05 level.

There were significant differences in various characteristics of the study plants due to the treatment (protection during 1 winter). Seed stalk production in 1987 was significantly greater at the 2 Hobble Creek sites. The Diamond Fork site had significantly lower seed stalk production on both browsed and protected plants in 1987. Considerable variation was noted in our data because seedstalk production is a function of genetics, plant age, vigor, climate, site characteristics, and browsing pressure. Variation in seed production among sagebrush populations of the same subspecies has been noted in other studies (Young et al. 1989, Wagstaff and Welch 1990). Seedstalk production on protected plants for 1984-1989 increased significantly $(P<0.05)$ on the Hobble Creek 1 site and for all plots in 1987. All browsed plants with the exception of those plots at the Diamond Fork site also had greater numbers of seedstalks in 1987. Browsed plants on all plots showed a return to low levels of seedstalk in 1989. Difference in production between years is probably due to a combination of factors including favorable moisture during the 1987 growing season. Additional information can be gained by looking at certain characteristics of the plants at each of the sites as shown in Tables 4 and 5.

We conclude that for the subject populations the protection of mountain big sagebrush plants from browsing by wintering mule deer for 1 winter resulted in an increased number of seedstalks.
Table 3. Seeds per seedstalk of single-stemmed and branched seedstalks of mountain big sagebrush in north-central Utah 1987.

\begin{tabular}{|c|c|c|c|c|c|c|}
\hline \multirow[b]{3}{*}{$\begin{array}{l}\text { Length } \\
\text { of stem } \\
\text { (cm) }\end{array}$} & \multicolumn{6}{|c|}{ Type of seedstalk } \\
\hline & \multicolumn{3}{|c|}{ Single stem } & \multicolumn{3}{|c|}{ Branched } \\
\hline & $\begin{array}{l}\text { Pct. with } \\
\text { No. } \\
\text { seed }\end{array}$ & $\begin{array}{c}\text { Max } \\
\text { No. } \\
\text { seeds }\end{array}$ & $\begin{array}{l}\text { Avg. } \\
\text { No. } \\
\text { seeds }\end{array}$ & $\begin{array}{l}\text { Pct. with } \\
\text { No. } \\
\text { seed }\end{array}$ & $\begin{array}{c}\text { Max } \\
\text { No. } \\
\text { seeds }\end{array}$ & $\begin{array}{l}\text { Avg. } \\
\text { No. } \\
\text { seeds }\end{array}$ \\
\hline $\begin{array}{l}0-15.24 \\
15.25-25.4 \\
>25.5\end{array}$ & $\begin{array}{c}50^{*} \\
33^{*} \\
0\end{array}$ & $\begin{array}{r}9 \\
104 \\
183\end{array}$ & $\begin{array}{r}6 \\
17 \\
69\end{array}$ & $\begin{array}{l}5 \\
3 \\
0\end{array}$ & $\begin{array}{r}115 \\
718 \\
1601\end{array}$ & $\begin{array}{c}8 \\
156^{*} \\
319^{*}\end{array}$ \\
\hline
\end{tabular}

*Significant at the 0.05 level.

Lengths of seedstalks were not significantly different at the 2 Hobble Creek sites and Diamond Fork. The length difference at Pleasant Grove in 1987 may be attributable to heavier use of browsed plants, which was also indicated by seedstalk numbers (Table 2).

The data led us to conclude that lack of seed production is not responsible for the low recruitment of plants in the study populations. We found no recruitment around study plants even though mountain big sagebrush has been noted for aggressiveness and ability to increase (Blaisdell et al. 1982). Still, it may be desirable to enhance seed production because mountain big sagebrush propagates only from seed and climatic conditions suitable for establishment occur sporadically (Johnson and Payne 1968, Brunner 1972, Young and Evans 1975, Caldwell 1979, Walton et al. 1986).

Several studies show a considerable variability in germination and establishment of seedlings due to a combination of climatic factors such as temperature and moisture (Johnson and Payne 1968, Young and Evans 1975, Harniss and McDonough 1976).

We could find nothing in the literature to indicate a method of predicting whether conditions favorable to seedling establishment would occur in any given year. In a recent study we found considerable seedling establishment in 1988, after seedbed preparation, at various levels of seed production and dispersal by mother plants,

Table 4. Selected characteristics of seed stalks on mountain big sugebrush plants on 1 site (Hobble Creek 1) in north-central Utah.

\begin{tabular}{|c|c|c|c|c|c|c|}
\hline Characteristic & 1984 & 1985 & 1986 & 1987 & 1988 & 1989 \\
\hline \multicolumn{7}{|l|}{$\begin{array}{l}\text { Seed stalks } \\
\text { max/plants }\end{array}$} \\
\hline $\begin{array}{l}\text { Protected } \\
\text { Browsed }\end{array}$ & $\begin{array}{l}182^{*} \\
26\end{array}$ & $\begin{array}{l}389 * \\
11\end{array}$ & $\begin{array}{l}419^{*} \\
12\end{array}$ & $\begin{array}{l}429 * \\
65\end{array}$ & $\begin{array}{c}432^{*} \\
14\end{array}$ & $\begin{array}{c}460^{*} \\
6\end{array}$ \\
\hline \multicolumn{7}{|c|}{$\begin{array}{l}\text { Percent of plants } \\
\text { with zero }\end{array}$} \\
\hline $\begin{array}{l}\text { Protected } \\
\text { Browsed }\end{array}$ & $\begin{array}{c}0 \\
20^{*}\end{array}$ & $\begin{array}{c}0 \\
10^{*}\end{array}$ & $\begin{array}{c}0 \\
10^{*}\end{array}$ & $\begin{array}{c}0 \\
10^{*}\end{array}$ & $\begin{array}{c}0 \\
10^{*}\end{array}$ & $\begin{array}{c}0 \\
10^{*}\end{array}$ \\
\hline \multicolumn{7}{|l|}{ Avg. length $(\mathrm{cm})$} \\
\hline $\begin{array}{l}\text { Protected } \\
\text { Browsed }\end{array}$ & $\begin{array}{l}28.6 \\
197\end{array}$ & $\begin{array}{l}21.7 \\
18.7\end{array}$ & 20.8 & 22.6 & 21.7 & 24.0 \\
\hline
\end{tabular}

*Differences significant at the 0.05 level.

Table 2. Average number of seedstalks per plant on mountain big sagebrush at 3 sites in north-central Utah.

\begin{tabular}{|c|c|c|c|c|c|c|c|c|c|}
\hline \multirow[b]{2}{*}{ Year } & \multicolumn{3}{|c|}{ Hobble Creek } & \multicolumn{3}{|c|}{ Pleasant Grove } & \multicolumn{3}{|c|}{ Diamond Fork } \\
\hline & Protected & Browsed & Increase & Protected & Browsed & Increase & Protected & Browsed & Increase \\
\hline $\begin{array}{l}1986 \\
1987 \\
1988 \\
1989 \\
\end{array}$ & 178 & $\begin{array}{l}11 \\
61 \\
18 \\
16\end{array}$ & $119^{*}$ & 153 & $\begin{array}{r}6 \\
11 \\
7 \\
5\end{array}$ & $142^{*}$ & 75 & $\begin{array}{l}5 \\
7 \\
6 \\
7\end{array}$ & $62^{*}$ \\
\hline
\end{tabular}

*Significant at the 0.05 level. 
Table 5. Selected characteristics of seed stalks on mountain big sagebrush plants on three sites in north-central Utah.

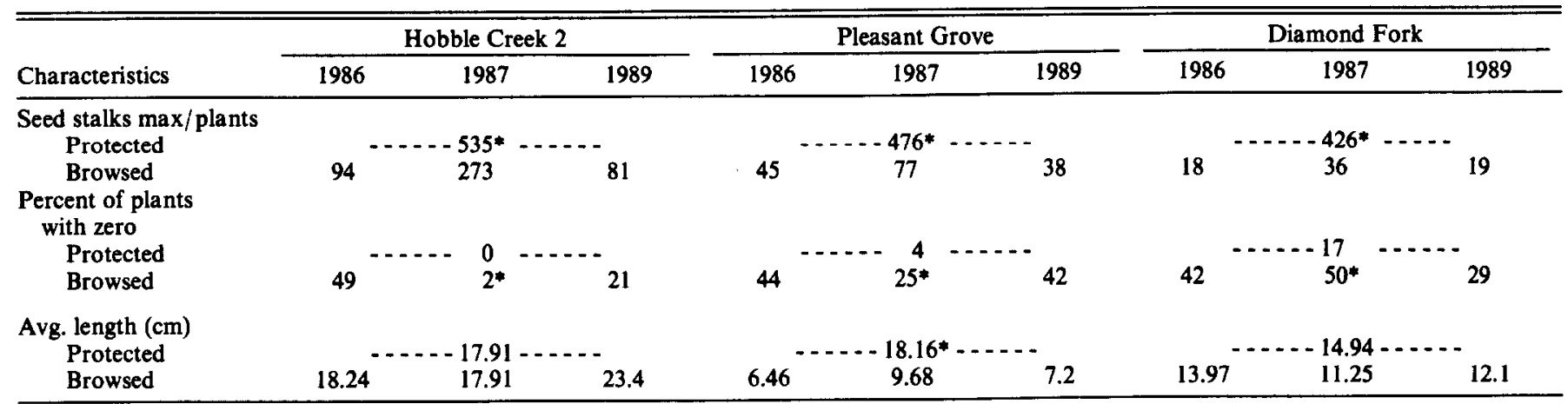

*Difference significant at the 0.05 level.

although that winter and spring set records for low precipitation (Wagstaff and Welch 1989).

Presence of seed is a necessary condition to seedling establishment, but other factors such as plant competition and climate may also be limiting. We found no seedlings on our study plots during 6 years of observations, even though many plants produced seed sufficient to cover the effective distribution area at a rate of several hundred seeds per square meter. Managing those factors that can be controlled, such as increased seed production, by protecting or otherwise controlling browsing levels may enhance the chances of establishing seedlings.

We have also observed that within the study populations, some plants are not browsed to the degree most other plants are. Because these plants are not used as heavily, they are producing far more seed and stand a greater chance of leaving progeny. Therefore, it seems possible that the more desirable plants will be the first to disappear from the populations, and unless they receive periodic rest they will leave insufficient progeny to replace themselves. The population structure would then shift toward a higher proportion of apparently less desirable plants.

\section{Literature Cited}

Beetle, A.A. 1960. A study of sagebrush. The section tridentata of Artemisia. Laramie, Wyo. Wyoming Exp. Sta. Bull. 368.

Blaisdell, J.P., R.B. Murray, and E.D. McArthur. 1982. Managing intermountain rangelands-sagebrush-grass ranges. USDA Forest Serv. Intermountain Forest and Range Exp. Sta. Gen. Tech. Rep. INT-134.

Brunner, J.R. 1972. Observations of Artemisia tridentata in Nevada. J. Range Manage. 25:205-208.

Caldwell, M.M. 1979. Physiology of sagebrush. P. 74-85. In: The sagebrush ecosystem-a symposium; 1978 April; Utah State Univ. College of Nat. Resour. Logan, Utah.

Cook, C.W., and L.A. Stoddardt. 1960. Physiology responses of big sagebrush to different types of herbage removal. J. Range Manage. 13:14-16.

Harniss, R.O., and W.T. McDonough. 1976. Yearly variation in germination of three subspecies of big sagebrush. J. Range Manage. 29:167-168.

Hironaka, M., M.A. Fosberg, and A.H. Winward. 1983. Sagebrush-grass habitat types of southern Idaho. Moscow, Ida.; Univ. Idaho, Forest, Wildlife, and Range Exp. Sta. Bull. 35.

Johnson, J.R., and G.F. Payne. 1968. Sagebrush reinvasion as affected by some environmental influences. J. Range Manage. 21:209-213

McAdoo, J.K., and D.A. Klebenow. 1979. Native faunal relationships in sagebrush ecosystems. P. 50-61. In: The sagebrush ecosystem, a symposium; 1978 April; Utah State Univ., College of Nat. Resour. Logan .

McArthur, E.D. 1983. Taxonomy, origin, and distribution of big sagebrush (Artemisia tridentata) and allies (subgenus Tridentatae). P. 3-11. In: Proc. 1st Utah shrub ecology workshop; K.L. Johnson (ed.). Utah State Univ., Logan.

McArthur, E.D., A.C. Blauer, and S.C. Sanderson. 1988. Mule deer induced mortality of mountain big sagebrush. J. Range Manage. 41:114-116.
McArthur, E.D., S.B. Monsen, and B.L. Welch. 1987. Shrubs and forbs for revegetation plantings in the sagebrush ecosystem. P. 29-39. In: Integrated pest management on rangeland-state of the art in the sagebrush ecosystem. J.A. Onsager (ed.). ARS-50; USDA Agr. Res. Serv., Springfield, Va.

Nagy, J.G. 1979. Wildlife nutrition and the sagebrush ecosystem. P. 164 168. In: The sagebrush ecosystem. A symposium; 1978 April; Utah State Univ., College of Nat. Resour. Logan.

Personius, T.L., C.L. Wamboldt, J.R. Stephens, and R. Kelsey. 1987. Crude terpenoid influences on mule deer preferences for sagebrush. J. Range Manage. 40:84-88.

Ryan, B.F., B.L. Joiner, and T.A. Ryan, Jr. 1985. Minitab Handbook 2nd ed. Duxbury Press, Boston, Mass.

Smith, A.D. 1949. Effects of mule deer and livestock upon a foothill range in northern Utah. J. Wildl. Manage. 13:421-423.

Smith, A.D., and D.M. Gaufin. 1950. The use of movable paddocks in the study of forage preferences of mule deer and livestock. Trans North Amer. Wildl. Conf. 15:512-518.

Wagstaff, F.J., and B.L. Welch. 1990. Rejuvenation of mountain big sagebrush on mule deer winter ranges using onsite plants as a seed source. P. 171-174. In: Proceedings-symposium on cheatgrass invasion, shrub die-off, and other aspects of shrub biology and management. Gen. Tech. Rep. INT-276.

Walton, T.P., R.S. White, and C.L. Wamboldt. 1986. Artemisia reproductive strategies: a review with emphasis on plains silver sagebrush. $\mathbf{P}$. 67-74. In: Proc. symposium on the biology of Artemisia and Chrysothamnus. Gen. Tech. Rep. INT-200, USDA Forest Serv., Intermountain Res. Sta., Ogden, Utah.

Welch, B.L. 1983a. Big sagebrush: nutrition, selection, and controversey. P. 15-19. In: Proc. 1st Utah ecology workshop; K.L. Johnson (ed.), Utah State Univ., Logan.

Welch, B.L. 1983b. Improving the nutritive value of winter range forage. $P$. 158-164. In: Managing intermountain rangelands-improvement of range and wildlife habitats. S. B. Monsen, and N. Shaw (compilers). Gen. Tech. Rep. INT-157, USDA Forest Serv., Intermountain Res. Sta., Ogden, Utah.

Welch, B.L., E.D. McArthur, D.L. Nelson, J.C. Pederson, and J.N. Davis. 1986. 'Hobble Creek'a superior selection of low-elevation big sagebrush. USDA Forest Serv. Intermountain Res. Sta. Res. Pap. INT-370.

Welch, B.L., E.D. MeArthur, and R.L. Rodriguez. 1987. Variation in utilization in big sagebrush accessions by wintering sheep. J. Range Manage. 40:113-115.

Winward, A.H. 1983. Using sagebrush ecology in wildland management P. 15-19. In: Proc. 1st Utah shrub ecology workshop. K.L. Johnson (ed.) Utah State Univ., Logan.

Winward, A.H., and E.W. Tisdale. 1977. Taxonomy of the Artemisia tridentata complex in Idaho. Moscow, Ida.; Univ. Idaho, Forest Wild. and Range Exp. Sta. Bull. 19.

Young, J.A., and R.A. Evans. 1975. Germinability of seed reserves in a big sagebrush community. Weed Sci. 23:358-364.

Young, J.A., R.A. Evans, and D.E. Palmquist. 1989. Big sagebrush (Artemisia tridentata) seed production. Weed Sci. Vol. 37. 